\title{
A science framework (SF) for agricultural sustainability
}

\author{
FERDOUS AHMED ${ }^{1}$, ABUL Q. AL-AMIN ${ }^{2}$, MUHAMMAD M. MASUD ${ }^{3}$, \\ FATIMAH KARI ${ }^{3}$ and ZEEDA MOHAMAD ${ }^{4}$ \\ ${ }^{1}$ Environnmental Science, Institute of Graduate Studies, University of Malaya, 50603 Kuala Lumpur, Malaysia \\ ${ }^{2}$ International Business School (IBS), University Technology Malaysia (UTM), Level 10, \\ Menara Razak, Jalan Semarak, 54100 Kuala Lumpur, Malaysia \\ ${ }^{3}$ Department of Economics, Faculty of Economics \& Administration, University of Malaya, 50603 Kuala Lumpur, Malaysia \\ ${ }^{4}$ Department of Science \& Technology, Faculty of Science, University of Malaya, 50603 Kuala Lumpur, Malaysia
}

Manuscript received on September 9, 2013; accepted for publication on October 24, 2014

\begin{abstract}
The significance of Science Framework (SF) to date is receiving more acceptances all over the world to address agricultural sustainability. The professional views, however, advocate that the SF known as Mega Science Framework (MSF) in the transitional economies is not converging effectively in many ways for the agricultural sustainability. Specially, MSF in transitional economies is mostly incapable to identify barriers in agricultural research, inadequate to frame policy gaps with the goal of strategizing the desired sustainability in agricultural technology and innovation, inconsistent in finding to identify the inequities, and incompleteness to rebuild decisions. Therefore, this study critically evaluates the components of MSF in transitional economies and appraises the significance, dispute and illegitimate issue to achieve successful sustainable development. A sound and an effective MSF can be developed when there is an inter-linkage within principal components such as of (a) national priorities, (b) specific research on agricultural sustainability, (c) adequate agricultural research and innovation, and (d) alternative policy alteration. This maiden piece of research which is first its kind has been conducted in order to outline the policy direction to have an effective science framework for agricultural sustainability.
\end{abstract}

Key words: Science framework, sustainable development, agricultural sustainability, research and innovation.

\section{INTRODUCTION}

Competence in developing and employing science and technology (S\&T) is increasingly acknowledged as an indispensable factor in approaches to generating sustainable development (Rukmani 2008, Leeuwis 2000, Cash et al. 2003). Attempts to supplement such aptitudes have been augmented since the beginning

Correspondence to: Ferdous Ahmed

E-mail: ferdous_raj@yahoo.com of the $21^{\text {st }}$ century due to the emergence of a concern to promote a global structure for research and relate it to S\&T (Busch et al. 1989, Carruthers and Tinning 2003, Koehnen 2011). Concerning S\&T and related research, the literature indicates that there have been a small number of associated triumphs and failures (Gibbons 1994). These reflect directives to show advances in competence (alternatively termed "efficiency") in relation to the understanding 
of and approaches to sustainable development, as well as to undertake the methodical research required to extrapolate from individuals' knowledge to attain a universal approach (Rahim and Emran 2012). In particular, such directives address types of agenda, academic requirements, societal provision and knowledge systems that are capable of connecting successful S\&T with effective sustainability (Mantell and Van-Hove 2008, Sandall et al. 2011, Hellin 2012). ${ }^{1}$ Agricultural operations and sustained development are not outside the realms of effective sustainability. Some of the earlier research guidance on agriculture has provided the foundations for working towards sustainability outcomes by developing fundamental technical concepts and there is recognition that there has been a considerable transmission of knowledge in relation to certain aspects towards these efforts (Mulder 2012). However, knowledge transmission in terms of a scientific framework that can be employed significantly on a social and regional basis in agriculture is unfortunately lacking with respect to many technical aspects.

Another lacking is the transfer of scientific research and development (R\&D) between the natural sciences $^{2}$ and agricultural sciences. For the transfer of scientific R\&D knowledge to be efficient, as expected, it is necessary to develop societal reactions in relation to shared concerns (so that the information is discerned by significant stakeholders); these must not only be realistic, but also relevant and valid (Rahim and Emran 2012). The transmission of scientific knowledge regarding $\mathrm{R} \& \mathrm{D}$ here indicates the "integrity (i.e. reliability)" of the link between

\footnotetext{
${ }^{1}$ Effective sustainabila four fundamental domains: ecology, economics, culture and politics.

${ }^{2}$ Namely physics, chemistry, medicine, and biology, as well as related fields.
}

technical competence and equitable attitudes in activities (Hellin 2012). Moreover, any related disputes or issues concerning needs, fairness and inefficiencies should be resolved and the salience of effective policies and choice selections focusing on the distant future should be ensured (Alauddin and Quiggin 2008, Hellin 2012, Sulaiman et al. 2012). Therefore, legitimacy ${ }^{3}$ in relation to needs, the validity of fair choice and the transfer of scientific knowledge in all sectors within an economy are vital parts of the construction of "integrity" (Buttel 1997). In addition, the incorrect selection of $R \& D$ knowledge and transmission can be overcome by an extensive process of learning from past mistakes. It is important to acknowledge the value of such tasks as a way forward, for example the work done "at the margins" by societal experts and policy makers (Rahim and Emran 2012). However, how technical competence can be transmitted fairly and equitably in an economy, for example through sanctions or compelling compliance from sectors, and issues of how to ensure technical equality and how to develop appropriate categorizations are still matters of debate in many countries, Malaysia in particular (Buttel 1997, Alauddin and Quiggin 2008, Sulaiman et al. 2012). The complexity of the successful diffusion of scientific R\&D in society as a result of the dissimilarities between the various groups, results in difficulties to bridge the gap in unsuccessful diffusion to make provision for sound economic growth particularly on margin-straddling organizations and activities in scatter-locations such as in Malaysia (Lederman 2006, Miller 2006).

Debates concerning the diffusion of scientific $R \& D$ between the natural sciences and other components of society continue to

\footnotetext{
${ }^{3}$ Legitimacy concerns the awareness of stakeholders with regard to ethics and equitable attitudes in relation to actions.
} 
this day, but in reality, a consensus must be attained with regard to integrity and work at the margins towards an effective framework for sustainable development employing science and technology (Rahim and Emran 2012). ${ }^{4}$ With regard to complexity, the European Commission has argued that the solutions to political and ethical dilemmas involving the scientific framework (science and technology) and other aspects of society (i.e. welfare-related aspects) cannot be resolved unless awareness on the part of stakeholders is explored. To ensure sustainability, any scientific framework should be both broad and applied to various parts of an economy, agriculture in particular. Studies by the Miller (2006) and Lederman (2006) indicate that the scientific framework should have some fundamental structures in terms of competencies to address the following aspects: i) to explain phenomena scientifically; ii) to design and evaluate scientific enquiry; iii) to interpret the data and evidence, scientifically; iv) to engage in rational trade-offs between economic needs and ecological capacity.

However, there must be integration in relation to the different scopes of such fundamental structures in terms of the ways in which the requirements for framework and policy equilibrium afford the integrity, salience, equity, justice and authenticity of the information (EASYPol 2006).

\footnotetext{
${ }^{4} \mathrm{~A}$ framework is a real or conceptual structure intended to serve as a support or guide for the building of something that expands the structure into something useful. It is more comprehensive than a protocol and more prescriptive than a structure. It denotes a set of beliefs, ideas, or rules that form the basis of a system or society, and relates scientific literacy matters at both national and international levels (Lederman 2006, Miller 2006). In particular, in relation to the issue of sustainability on agriculture it highlights the availability of sufficient water, food security, disease control, and the generation of adequate energy, including that if adapting to climate change.
}

In addition, there must be coherent trade-offs between societal needs and ecological capacity to maintain long-term environmental governance. ${ }^{5}$ If the societal need is greater than ecological capacity, there should be an ecological intervention ${ }^{6}$ that outlines materialization from early scientific innovations to top-level guidelines (Anderson and Valenzuela 2009). Hence, the "efficacy" of technical contributions is vital; however, there are issues in terms of how this is to be estimated, the outlining of distinct research questions and alternative measures for addressing problems, rather than simply what processes may be employed to address ecological evils. Therefore, $R \& D$ related to equity is required to address problems and measurements (Anderson and Valenzuela 2009). Only then approaches to generating sustainable development will be promising and will be integrating in achieving an articulation of a plan.

Sustainable development is a concept comprising a variety of approaches that relate to how problems are originated and to how procedures are planned to address them (Cerfetal. 2011, Koutsouris 2008). What is meant by sustainable development according to governments, environmental activists, businesses and social reformers? It is regarded as the juncture between society, the economy,

\footnotetext{
${ }^{5}$ Meadows et al. (1992) argue that "if the present growth trends on world population, industrialization, pollution, food production and resource depletion remain unchanged, the limits to growth on this planet will be reached sometime within the next 100 years". There is no doubt that as ecological resources are limited, there should be a balance in economic activities to maintain the ecological capacity for future generations.

${ }^{6}$ If there is a deviation of proper environmental policy that advocates sustainability to maintain social and economic and political activities, and if environmental policy is unable to address environmental issues effectively, it may disturb the proper functioning of the cycle of ecological capacity and would affect business, civil society and government as a whole in the ecological management system (Anderson and Valenzuela 2009).
} 
government and the environment, all of which are distinct but associated entities (Reed et al. 2006). We disagree with the view that sustainability issues are not integrated with these entities, but rather consider that they are somewhat fractured and multifaceted, particularly the fact is that they are measured in diverse options. Very often the economy is prioritized in guidelines and the environment is analyzed as separate from human beings (Bockstaller et al. 1997). However, there are interrelationships in sustainable development as the economy relies on the community and the environment; man's survival and civilization is subordinate to and within the environment. Therefore, the links between integrity and technical competence with the critical notions raised earlier, such as ethical issues, equity, technical equality and suitability, are very important based on societal needs. However, R\&D issues, knowledge transfer and the division between the economy, society and the environment, frequently results in a constricted techno-scientific approach, whereas the debates in which the civilization needs to engage in terms of the current socioeconomic formation are regularly overlooked, and primary discussion concerning sustainable societies and the diversification of literature is mostly absent (Fraser et al. 2006).

It is recognized that science-based knowledge is the key factor in technological development related to economic growth and development (Cash et al. 2003). Here, a knowledge-based economy is crucial in moving towards a science-based economy (Hezri and Hasan 2004). New information such as development of science is progressed by generating investigation and assessment (Hopwood et al. 2005). Research and development (R\&D) strategy is the fulfillment of market requirements and reveals of associated difficulties how to overcome (Hopwood et al. 2002). Hence, innovations are used to derive advantages from technology, invention and services thus result in greater economic growth and productive wealth (Bell and Morse 2004).
The evidence is well-built by the integration of the different scopes on sustainable development to enhance the advanced economics. ${ }^{7}$ Is the dissemination of scientific knowledge capable of responding to concerns in all parts of the economy? This is the critical issue we aim to address in our research and we also intend to identify the gaps in the science framework related to agricultural sustainability.

This research comprises a case study in Malaysia designed to evaluate sustainable development with a view to developing an effective science framework for agricultural sustainability. In particular, it addresses the following research issues:

- To what extent has Malaysia been successful in rebuilding its agro-economy through industrialization ${ }^{8}$ In particular, here we consider the fact that the contribution of agriculture to the national gross domestic product (GDP) appears to be negligible (Figure 1).

- What are the lessons to be learned by policy makers?

- What is the way forward to resolve the issue of agricultural sustainability?

We understand that there are some policy gaps in relation to strategies concerning the choices made on national agenda for agricultural sustainability. There may some gaps in the understanding of and the focus on economic growth and productive wealth distribution.

\footnotetext{
${ }^{7}$ Malaysia is considered a developing to advanced economy and trying to catching up the innovations that are used to derive advantages from technology.

${ }^{8}$ Although Dr Mahathir Bin Mohamad (the former Prime Minister) was successful in rebuilding Malaysia's economy through industrialization; he has often been criticized for his negligence in addressing food security and agricultural sustainability issues. Despite having considerable legitimacy, agriculture was again emphasized in the ninth Malaysian Plan during the state power of Mr Abdullah Ahmad Badawi (former Prime Minister) in 2006 (Ministry of Finance, Malaysia).
} 
Furthermore, the focus on R\&D related to the natural sciences over the last two or three decades may have delayed progress on the development of sustainability in the potential parts of the economy. Hence, the effectiveness issue, particularly for agriculture, is not commonly addressed in Malaysia. That is why it is important to promote the understanding level of sustainability and undertake methodical research in relation to agriculture.

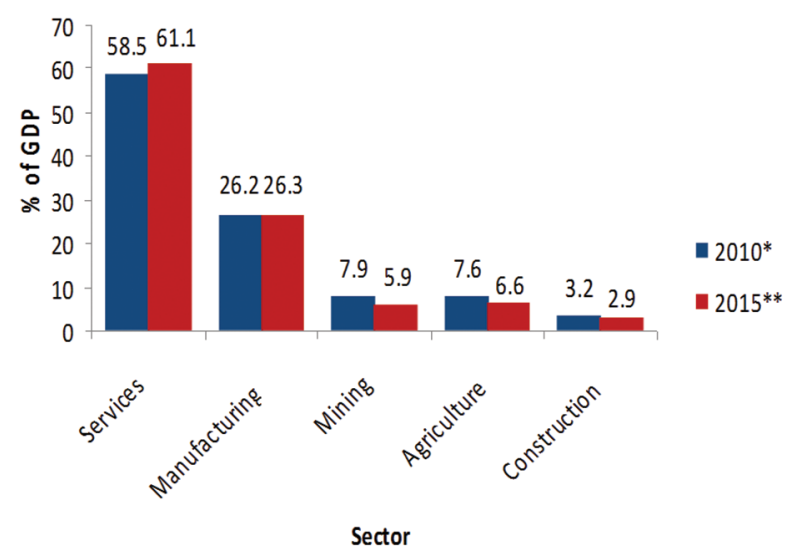

Figure 1 - National Economic Sectors as \% of GDP contribution. Source: Economic Report 2009-2010 (DOS 2010); RMK 10 Report (EPU 2014).

Malaysia needs to embrace the mega-science approach, incorporating science, technology, and innovation (STI), to lead the sustained growth of the economy towards long-term sustainability. Mega science adopts the intensive, extensive and in-depth use of knowledge to generate products, technologies and services in all aspects of economic growth and sustainable development (Rahim and Emran 2012). Nowadays, the question most commonly asked by policy makers is how STI can aid economic growth without compromising environmental sustainability (Bossel 1998). Unfortunately, over the last 30 years, the implementation of anthropogenic STI methods worldwide has transformed food production, consumption, transportation, health, and communications in such a way that is resulted in unsustainable changes in climate patterns. However, the initiatives and outcomes have thus far been ignored (Corbiere-Nicollier et al. 2003). Furthermore, Malaysia has the capacity to transform its economy more productively due to the huge biodiversity of its natural resources, but this has not yet occurred.

There are vast opportunities in various sectors of the national economy which can be leveraged to resolve the challenges and problems faced in agriculture. This could be achieved through innovative approaches in the application of science, engineering and technology (SET), or research and extension (Alston et al. 1998, Mullen et al. 2000). Identifying and developing various tools through SET could ensure the benefits of Malaysian economy in a sustainable manner (Navarro 2006). A considerable body of literature, including contributions from Hellin (2012), Mulder (2012), Prasad (2012), Baerenklau and Keith (2007), Sharmistha (2007), Rao and Hanumantha Rao (2005) reflect the needs and issues of sustainable development, which provides innovation both in the national and international arenas. However, from the Malaysian perspective, unfortunately, effective initiatives are limited. Therefore, this study has taken the initiative to mitigate the limitations in the Malaysian context by introducing an additional guideline in relation to SET for the Mega Science Framework (MSF) and aims to provide a recommendation for a scientific framework that is applicable and effective in terms of sustainable growth with particular reference to agriculture.

\section{STUDY OUTLINE}

To our knowledge, no extensive scientific research has been done on agricultural sustainability in Malaysia. As the Malaysian government is dependent primarily on the service and manufacturing sectors, there is still a gap in national policy related to the agricultural sector, which is given less priority (EPU 2006, Rahim and Emran 
2012). It is regrettable that even though Malaysia has a huge land area of which $60 \%$ is forest, a very important indicator for sustainable agriculture, policy makers have failed to develop innovative strategies for the agro sector (Rahim and Emran 2012). Furthermore, the contribution of agriculture to national GDP has decreased dramatically in most developing nations over the last two decades, this is quite noticeable in Malaysia as well (Athukorala and Loke 2009, Arshad et al. 2010). ${ }^{9}$ Table I shows the comparative expenditure $(\mathrm{Rm})$ ratio between national R\&D and endowment to agriculture. ${ }^{10}$ The endowment ratio decreased for agricultural $R \& D$ in all major master plans from 2001 to 2011 and also does so in the forthcoming master plan for the year 2015 (EPU 2014).

TABLE I

Comparative expenditure (RM) ratio between research \& development (R\&D) and Agriculture.

\begin{tabular}{ccccc}
\hline $\begin{array}{c}\text { S1 } \\
\text { No }\end{array}$ & $\begin{array}{c}\text { Malaysian } \\
\text { Plan }\end{array}$ & Year & $\begin{array}{c}\text { Research \& } \\
\text { Development }\end{array}$ & Agriculture \\
\hline 1 & $6^{\text {th }}$ & $1990-1995$ & 1.8 billion & 821.4 million \\
2 & $7^{\text {th }}$ & $1996-2000$ & 10 billion & 7.5 billion \\
3 & $8^{\text {th }}$ & $2001-2005$ & 14.7 billion & 7.9 billion \\
4 & $9^{\text {th }}$ & $2006-2010$ & 89.8 billion & 11.4 billion \\
5 & $10^{\text {th }}$ & $2011-2015$ & 150 billion & 3.4 billion \\
\hline
\end{tabular}

$\mathrm{RM}=$ Malaysian Ringgit.

Source: Economic Panning Unit (EPU 2014).

However, expert views suggest that unless there is some sustainable agriculture, ${ }^{11}$ it is doubtful that

\footnotetext{
${ }^{9}$ In particular, there has been an emphasis on electronic and electronic-related products, manufacturing, DNA and molecular technology, renewable energy, services and communications (Arshad et al. 2010, Athukorala and Loke 2009).

${ }^{10}$ Malaysia intensified its focus on innovation in technology, particularly in manufacturing, in its $9^{\text {th }}$ and $10^{\text {th }}$ Master plans; however, put innovation and sustainability issues in relation to agriculture on the back burner (Table I, EPU 2014).

11 Sustainable agriculture requires proper management with technological support, for example in relation to sufficient water sources, disease control, R\&D for future innovation, agrobiotechnology, bioremediation and agro-engineering in adapting to vulnerability resulting from climate change or related matters.
}

the goal of achieving meaningful sustainable development could be attained. Therefore, the Malaysian government should realize the importance of sustainable agriculture. So that it could contribute to the national GDP significantly in the future. A balanced economy could be achieved for long-term sustained economic growth, even if Malaysia experiences effects from climate change or a meltdown in foreign investment over time.

In this era of globalization, very few boundaries remaining between most fields; in fact, there is an interlinking or connectivity among the various knowledge domains (Rahim and Emran 2012). However, information and communication technology could be potential for the agriculture and especially by applying a multidisciplinary approach. The collective knowledge embedded in a multidisciplinary approach can be innovative, extending and giving new meaning to agriculture. Hence, there is great potential to regain predictability in agriculture ${ }^{12}$ and it may be possible to enhance knowledge in different fields of study, including agro-forestry, the environment, agro-biotechnology, bioremediation, ecotourism, and agro-tourism (Manap 1986). A multidisciplinary approach employing the $\mathrm{MSF}^{13}$ could combine sustainability knowledge, open up new understanding, develop concrete capabilities, provide new scopes, and ensure comprehensive and diversified food security

\footnotetext{
${ }^{12}$ The predictability of agriculture (or the lack of it) relates to the gap between potential production of agricultural products and production lost for one or other reason (e.g. poor management, ineffective strategy, climate change, or lack of proper research, development and innovation). These gaps would be minimized by the proper application of the MSF, for example by utilizing modern innovation and R\&D, namely agro-biotechnology, bimolecular and bioremediation.

${ }^{13}$ The MSF is here not only a science-based innovative framework but is also related to socio-economic engineering in the context of the techno-centric paradigm, adopting a different approach that has a multilevel perspective and takes stakeholder priorities into consideration.
} 
for the value chain and deliverance system in relation to long-term product development with sustainability. ${ }^{14}$ However, this would necessitate the injection of significant funding, with the provision of large budgets for biotechnological and bimolecular research. For example, recombinant DNA technology can be used to produce bio-steel by introducing a protein silk production gene generated from spiders into goat's milk through molecular technology (Ervin et al. 2010). The knowledge domains of biopharmaceuticals, agrobiotechnology, molecular biology, nanotechnology and nutraceuticals can shape agriculture frontiers and related areas of knowledge (Aldy et al. 1998). It is also possible to converge and link with other disciplines, creating new job markets, opportunities, possibilities and product development for sustainable food security (Liu and Zhang 2011).

\section{THE MSF AND ITS LIMITATIONS}

Recently, Academy of Sciences Malaysia (ASM) proposed the MSF as a guideline for the sustainability of the future agricultural agenda in the hopes of generating sustainable development (Rahim and Emran 2012). The main focus of the MSF is to merge biodiversity, agriculture, energy, health and water issues to represent sustainability and comprehensiveness in the New Economic Model (NEM) of Malaysia (Rahim and Emran 2012). The concept of the MSF focuses on a multidisciplinary approach and multidisciplinary knowledge, incorporating technical fields that can promote pioneering methods for sustained and scientific agricultural practices to support the NEM. However, disputes related to privatization

\footnotetext{
${ }^{14}$ The key research questions embraced in the MSF include how effective and efficient technology can change existing technical systems and how innovation can enhance future ability by transferring knowledge, considering various possible alternatives. The underlying paradigm considers it possible to negotiate the trade-off between societal needs and future development in a manner that produces a win-win situation.
}

issues regarding the New Economic Policy (NEP), which was replaced fully by the NEM, ${ }^{15}$ have given rise to questions concerning integrity and work at the margins (Rahim and Emran 2012). Therefore, the legitimacy of information and knowledge in the NEP is questioned by stakeholders because of contradictions with regard to ethics and equitability (Zainal et al. 2008). This indicates the limitations of the MSF in terms of implementing the desired agricultural sustainability.

Therefore, it is clear that Malaysia's proposed model in the MSF is not converging effectively to provide sustainable agriculture. The expert view suggests that the NEM does not strategize for sustainability as it puts more emphasis on the private sector (EPU 2006). However, privatization results in some sectors to fall in the deficient market mechanisms. This market mechanism also can be resulted in more disputes as it is based on the unequal distribution of natural resources in the NEP (NEP 2010). Moreover, the propaganda of privatization is criticized as it is based on the elite class and focuses less on effective sustainability for the poor whose livelihood depends on agriculture.

Ensuring effective sustainability in agriculture is very important to support growing requirements, for example in relation to quantity, quality and the provision of multi-faceted agricultural products

\footnotetext{
${ }^{15}$ The NEP was a restructuring action programme launched in Malaysia by the former Prime Minister, Tun Abdul Razak, in 1971 and it was succeeded by the National Development Policy in 1991. It was essentially an ambitious socio-economic affirmative action programme, which was partly against privatization and was controversial as its ideas were based on socialism. However, to increase per capita GDP in the late $1990 \mathrm{~s}$, the Malaysian government introduced the NEM, replacing the NEP. Its aim was to transform the economy into one with high income rates and quality growth, as well as containing key plans for high income, sustainability and inclusiveness. In particular, the goal of the NEM is to stimulate economic growth by improving worker productivity across all sectors of society, in part through an improved system of affirmative action, with an eye towards sustainability which is managed directly and indirectly in the MSF.
} 
and services for agricultural sustainability and food security. However, the integrity of the transmission of scientific knowledge would be unrealistic, irrelevant and invalid if the NEM were implemented to its full extent (NEP 2010). To establish effective integrity, there is a great need to locate elements that are lacking in policy and identify a way forward to overcome barriers to equality in order to ensure feasible and sustainable development. Finally, there is a need to establish answers to the following research questions concerning the MSF:

- At what point are we now?

- What are the phenomena on which we should be focusing?

-What intrinsic compensations can we obtain?

-Where should we be positioned as a country?

- How may we achieve the goal of 2050 working together?

- Can these efforts help determine a successful roadmap?

IMPROVEMENT OF THE MSF USING AN EFFECTIVE

KNOWLEDGE MANAGEMENT SySTEM

From perusing the relevant literature, it is apparent that the barriers to the MSF require a feasible solution to achieve sustainable agricultural development; thus, Malaysia should remodel its policies to generate an improvement in knowledge by including a good number of universities and research institutes in the process. The mega science approach must highlight the need to reinforce R\&D policies for non-traditional sectors along with modernization. To strategize with a view to realizing the entire potential of sustainability, implementing R\&D is essential. Hence, a mega science strategy should recognize a R\&D policy that can be acted as the optimum indicator for all the specified sectors related to economic growth and development. Figure 2 shows low R\&D investment in Malaysia compared to other advanced economies. To attain this target in the NEM, the Malaysian government should increase at least $2 \%$ expenditure in S\&T activities. The NEM aims to achieve an effective knowledge management system by 2020 (NEP 2010). However, according to the investment scenarios shown in Figure 2, the Malaysian figures are not at all impressive in terms of attaining a sound MSF that can determine the future agricultural agenda for sustainable development.

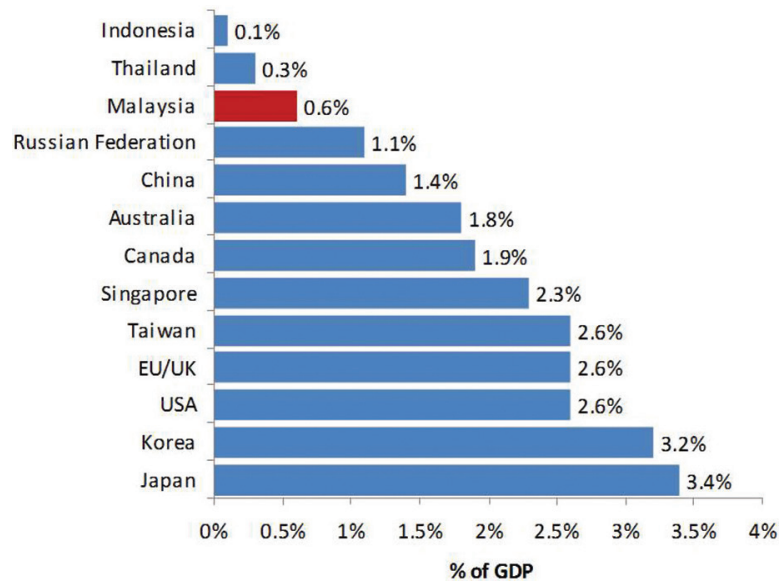

Figure 2 - Malaysia's low R\&D investment and GERD to GDP Expenditure by Country. Source: APEC Industrial Science \& Technology Internationalization Database (2010), adopted from MSF (2010).

$R \& D$ requires a long period to demonstrate benefits, unlike the benefit in national GDP derived through commercializing knowledge and research findings (Figure 3). To obtain widespread, persistent and rigorous benefits from $R \& D$ activities, a longterm $R \& D$ vision is required, involving bold, up-front investments for agricultural sustainability (Pardey et al. 2006). As there are financial constraints, it is difficult for a country such as Malaysia to make the necessary investments that could generate significant strides in an approach towards the MSF. Therefore, we emphasize that a long-term strategy should be implemented extensively in the agricultural sector (Alston et al. 2000). Otherwise, the transmission of scientific knowledge would be no more than a policy issue on the agenda. Therefore "integrity" in relation to technical competence with salience for 


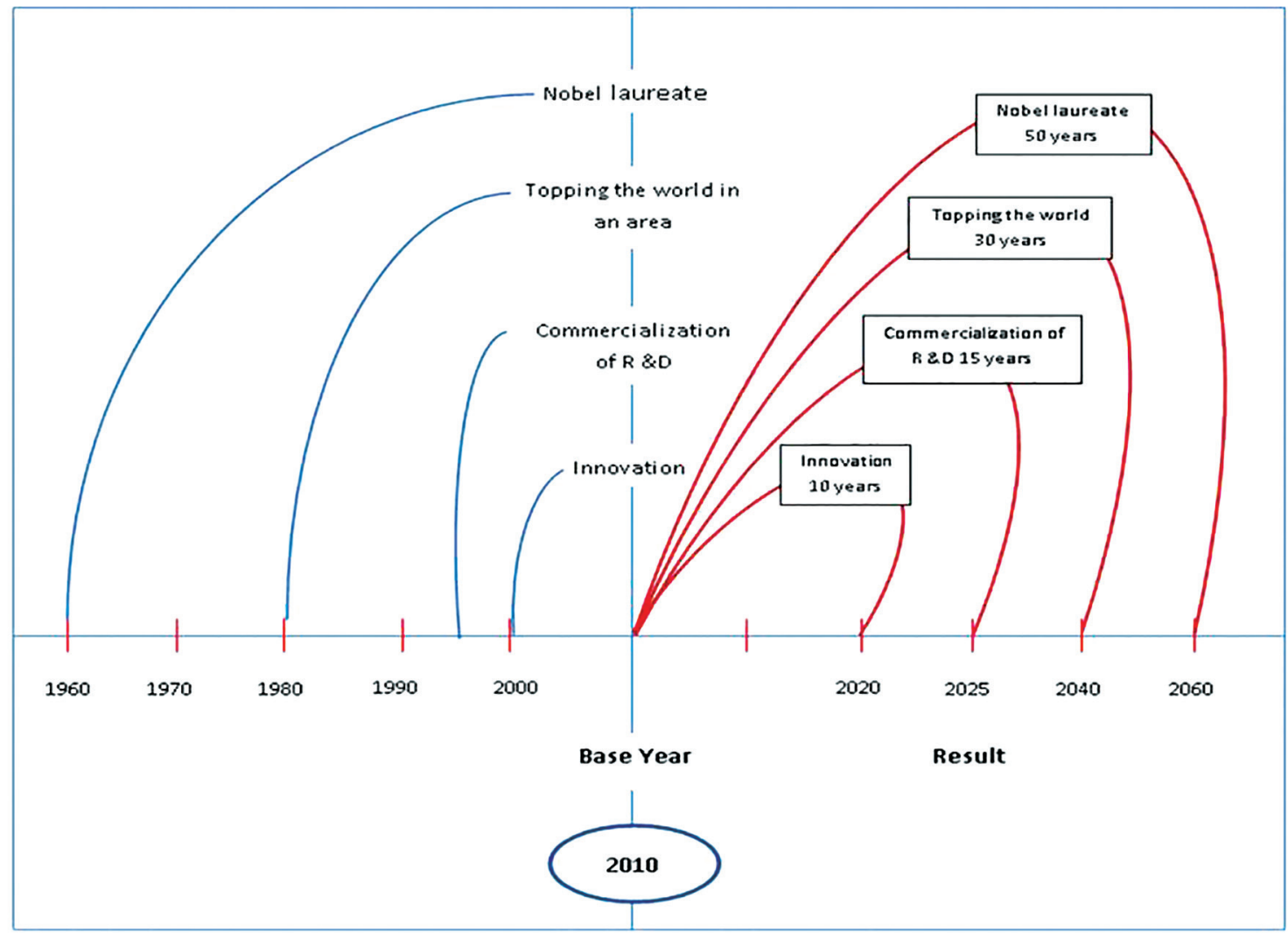

Figure 3 - Time Lags on Increase in HR and R\&D Investments and the Resultant Key Indicators Stimulating Economic Growth. Source: Sustaining Malaysia's Future, The Mega Science Agenda, 2011 (MSF 2010).

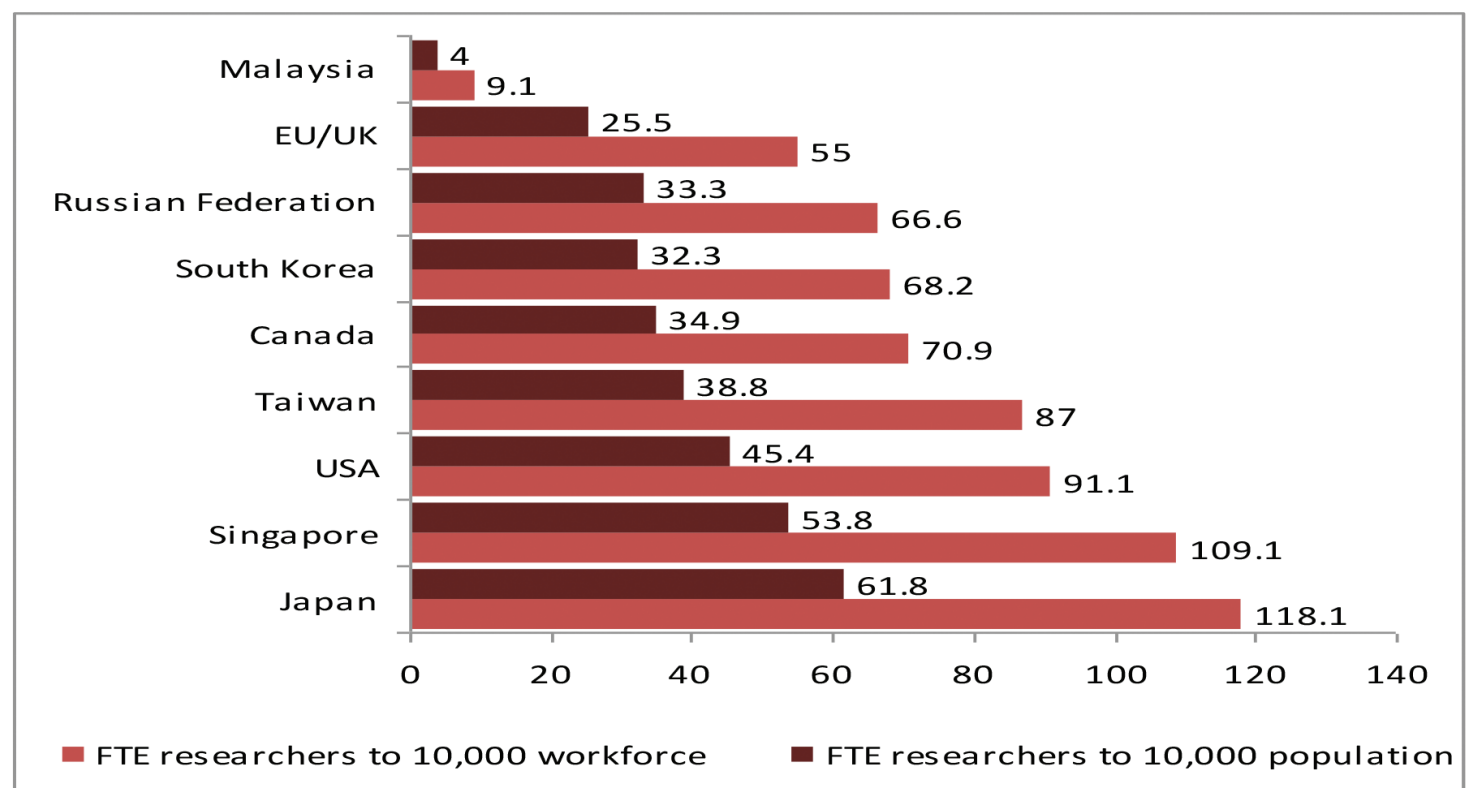

Figure 4 - Low Full Time Equivalent (FTE) - A barrier to sustained economic growth. Source: (1) APEC Industrial Science \& Technology Internationalization Database, 2010. And (2) National Survey of Research \& Development, 2008; adopted from MSF (2010). 
effective policies and the outcome of MSF, would be unrealistic, irrelevant and illogical. Although the Malaysian economy is slowly developing based on industry and manufacturing, there are nonetheless several knowledge gaps in agricultural sectors, both in terms of theoretical and applied aspects of research. ${ }^{16}$ In particular, finding the optimal solution requires a sound and effective concentration of technological knowledge and sustainable economic development (Navarro 2006, Hellin 2012, Mulder 2012). In addition, for every 10,000 population there is a full-time equivalent(FTE) researcher in Malaysia. However they are low-waged compared to other advanced and transitional economies (Figure 4). ${ }^{17}$ Does this mean that Malaysia is not on the right track to fulfill the aims of the MSF by 2020? It certainly appears that the proposed MSF is currently unable to identify gaps and a way forward to address the required objectives through knowledge management.

FUNDING OPTIONS AND INNOVATION

The Malaysian government contains diverse ministries concerned with agriculture and its related fields. Among these, the Ministry of Agriculture and Agro-Based Industry, the Ministry of Natural Resources and Green Technology, the Ministry of Science, Technology and Innovation, the Ministry of Education and the Ministry of Domestic Trade and Industries are the most relevant (EPU 2006); the large number of ministries that directly or indirectly oversee the agricultural sector and share responsibility results in bureaucratic obstacles to providing research funding for technology and innovation (DOS 2010). There are some funding

\footnotetext{
${ }^{16}$ It is presumed that the growth of the economy may drop in the future due to the growing population and improper use of renewable and non-sustainable resources. However, there is a way of overcoming the constraints by managing natural and environmental resources. Hence, the growth of the economy should not only depend on resources and expertise but also on sustainable natural resource management, for example in relation to land, forestry and water, as well as building environmental capacity.
}

sources available for agricultural research, such as the Prototype Research Grant Scheme (PRGS), the Exploratory Experimental Research Grant Scheme (ERGS), the Long-Term Research Grant Scheme (LRGS), the Research University Grant Scheme (RUGS), the Agricultural Research Fund (ARS), the Fundamental Research Grant Scheme (FRGS), and the Malaysian Palm Oil Board fund for research (CESS). However, unfortunately most of the research grants have various limitations. First, the amount of research grant tends not to be adequate for studies in agricultural technology and innovation. Second, most of the grants are conditional, which sometimes discourages research scientists from applying (Blackmore et al. 2002).

Therefore, the outcomes of MSF studies are always questionable and private investors are gradually becoming discouraged from taking part in enhancing the framework. ${ }^{18}$ The perspective of some developed and emerging countries, which made an allocation to generate the R\&D agenda, could be used as a model (Chichilnisky 1994). According to the EU (European Union) country report of 2011 on South Korea, it increased its funding for R\&D to up to $28.7 \%$ from $24.3 \%$ in 2005 (EU 2011). This means that the South Korean government increased the funds available for research and innovation by $1.1 \%$ on average per year. The United States (US) is the leading country in research and its research fund is one of the largest for agricultural technology and

\footnotetext{
${ }^{17}$ The transitional economies included here are neither fully developed nor developing countries, but are changing gradually from centrally planned economies to a free market (i.e. Russian Federation).

${ }^{18}$ Private investors may play a vital role in sustaining MSF studies involving different agricultural practices such as those related to food, fuel, fiber, pharmaceuticals, etc. They can promote agricultural knowledge and networks to design and conceptualize three-layered economic development models including agrarian, industrial and knowledge based agricultural aspects.
} 
innovation (EU 2011). The research budget of the US Department of Agriculture (USDA) is funded by two different organizations: the Agricultural Research Service (ARS) and the National Institute of Food and Agriculture (NIFA). The US government is prioritizing research and innovation for the agro sector through a policy which is supposed to increase research funding (EU 2011). Now the question is that how Malaysian government can effectively manage funds to implement MSF studies. Although the ruling government has a plan to apportion RM20 billion (US\$1 = RM3.10) for increased science production by 2020, it is still not enough to attain an increment in R\&D activities (Aminuddin et al. 2005). The Special Innovation Unit (SIU) of the Malaysian Prime Minister's Office could take necessary steps to spread and introduce the R\&D activities in the country. It is also important to establish what percentage of the total grant could be provided by the private sector. Figure 5 illustrates the regional shares of public agricultural research expenditures.
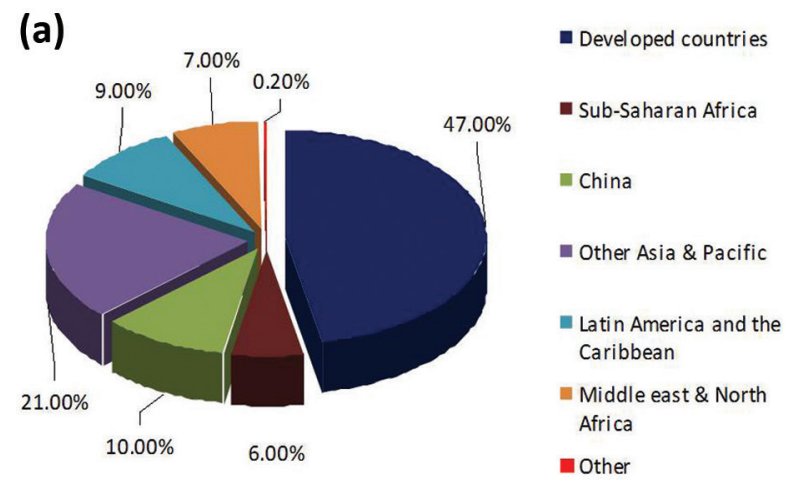

(b)

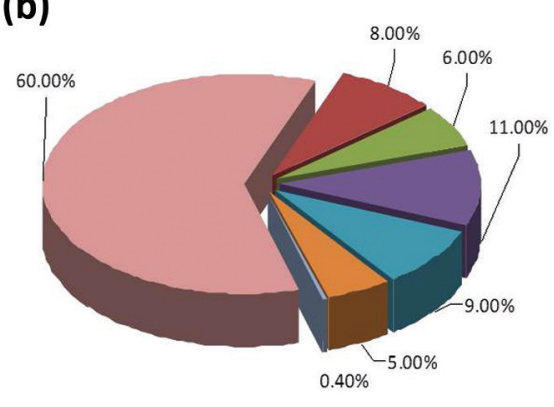

Devel oped countries

- Sub-Saharan Africa

China

- Other Asia \& Pacific

- Latin America and the Caribbean

- Middle east \& North

Africa

m Other

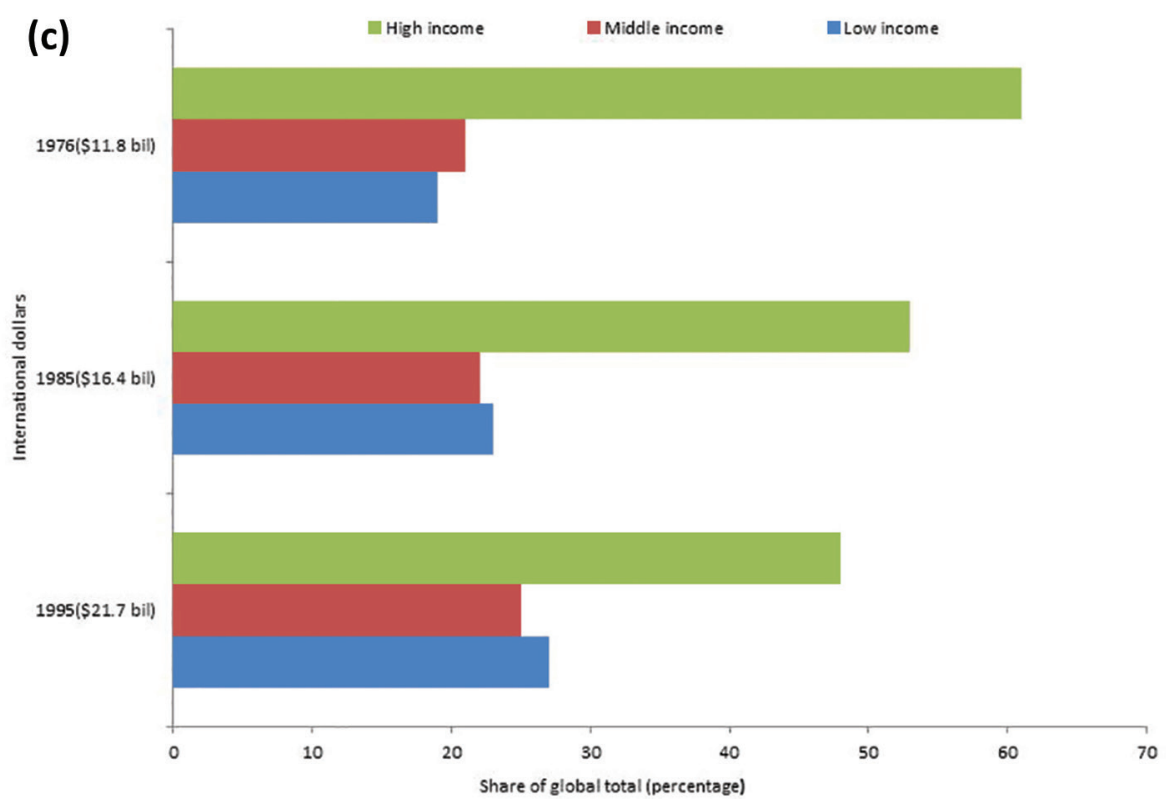

Figure 5 - a, b: Regional share in public agricultural research expenditures, 1976 and 1995, c: Public agricultural research spending by income class, 1976-1995. Note: Low income $=<\$ 726$ per capita/year. Middle income $=\$ 726-8,955$ per capita/year. High Income $=$ $>$ \$ 8,955 per capita/year. Source: MSF (2010). 
A WAY FORWARD IN DEVELOPING AN EFFECTIVE MSF

Currently, one of the most important items on the agenda of Malaysian policymakers where to embed MSF studies towards the country's agricultural sustainability by the year 2020. There are some limitations, but it is possible to strategize and adopt some policy options in the years to come in order to mitigate them. The positive experiences of sustainable management policy from other developed or developing countries should be considered and evaluated to determine possible routes for long-term achievement of agricultural sustainability in Malaysia. Moreover, research collaborations or research exchange programmes with institutions in other developed countries should be pursued to increase knowledge of agricultural technology and innovation. Most of the cultivated land in Malaysia is devoted to oil palm, rubber, cocoa, coconut, rice and various orchard crops. There is huge potential for implementing the MSF, investigating various mechanisms and employing technological innovations to improve the pattern of land use. To maximize agricultural quality and productivity, an augmented agro-ecosystem and scientific and technological approaches are essential. Work on genomic traits opens up new avenues of research for viable plants and cash crops, such as rice, maize, cereals and other food crops, as well as fiber, fuel, feed and pharmaceuticals. Therefore, potential options for the strategy of MSF, such as genomics management, should be considered. ${ }^{19}$

The Malaysian MSF has the potential to enhance bio-wealth prospects through research on the genomics of species belonging to both flora and fauna. It has already been proven that genomic traits can considerably improve agricultural production through the advanced technology of

\footnotetext{
${ }^{19}$ In light of innovative science framework, China has progressed DNA genome mapping and sequencing of more than 100 crop plants which are proving to be economically profitable.
}

agro-biotechnology and molecular breeding (Fan et al. 2006). What can be done using these biological technologies for the welfare of agriculture in Malaysia? Through a widespread, persistent and rigorous focus on $\mathrm{R} \& \mathrm{D}$ activities and a long-term $\mathrm{R} \& \mathrm{D}$ vision, the Malaysian MSF could enhance crop production, yields and resistance to pests and weeds, as well as improve tolerance to increased temperatures, drought and floods. The functions of ICT, biodiversity conservation, water technology and agro ecosystems must be included in the focus of the MSF. Several essential technologies and technological innovations can be employed to address the shortcomings of the MSF, such as (a) the transplantation of bio-geographical species, (b) plant and crop gene technology, (c) innovations in fisheries and aquaculture, (d) sustainable rural and urban agriculture, (e) low carbon crops and green technology, (f) improvement of ICT based applications, (g) sustainable water technology, (h) research exchange among ASEAN countries in relation to agriculture, (i) human capital in agriculture, and (j) food safety and nutrition.

\section{DISCUSSION}

There is no doubt that the MSF is crucial in meeting the increasing demand to achieve sustainable agriculture. Consequently, the science framework should be linked to every aspect of agriculture; otherwise, the MSF will remain far from achieving sustainable development in food security. There are many issues with the agro sector, such as the lack of appropriate policy, constraints and risk management, which constitute barriers to agricultural development. Malaysia could adopt the model of Competitive Agricultural Technological Funds (CATF) to achieve the agricultural sustainability. ${ }^{20}$ This model

\footnotetext{
${ }^{20}$ Bureaucratic constraints and the use of conventional methods in agricultural research have, in developing countries, led to funds being directed to agricultural technology.
} 
has been introduced in Latin American countries over the last three decades to advance agricultural technology, promoting agricultural research under a long-term framework. The key to this model is to select areas on a priority basis. Technology transfer is a vital issue in some developing countries such as Malaysia. ${ }^{21}$ Therefore, the issue is how Malaysia could strategize a new approach to technology transfer and in particular the four critical steps: i) knowledge management; ii) gap-filling research; iii) providing support and guidelines to the private sector; and iv) analysis of environmental impact.

Technological innovation in agriculture based on a multidimensional model is of considerable importance in Malaysia (Figure 6). Agricultural innovation comprises multiple actors, factors and levels and can be embedded in the MSF through co-evolutionary methods that combine all these effectively. Innovation in the MSF can be extended further following Gibbons et al. (1994) for the practices of sustainable agriculture. This innovation system for agro production and conventional science can be enhanced in two ways: i) merging multidisciplinary approaches and ii) aggregating the research knowledge of concerned scientists and stakeholders. There are disputed aspects of this mode which can be overcome by fostering greater awareness among researchers and stakeholders to build knowledge dynamics and the necessary expertise for further technological innovations. ${ }^{22}$ The main barriers to the implementation of the MSF in Malaysia are funding constraints in agricultural research and a lack of support for research in higher education.

\footnotetext{
${ }^{21}$ This is in contrast to the present state and prospects of developed countries such as the US and Japan, where research in this field is quite advanced in terms of the practice of technological transfer.

${ }^{22}$ As a result, a combined initiative on the part of European scientists, policy makers and implementers suggest the fundamentals of the road map towards sustainable agriculture.
}

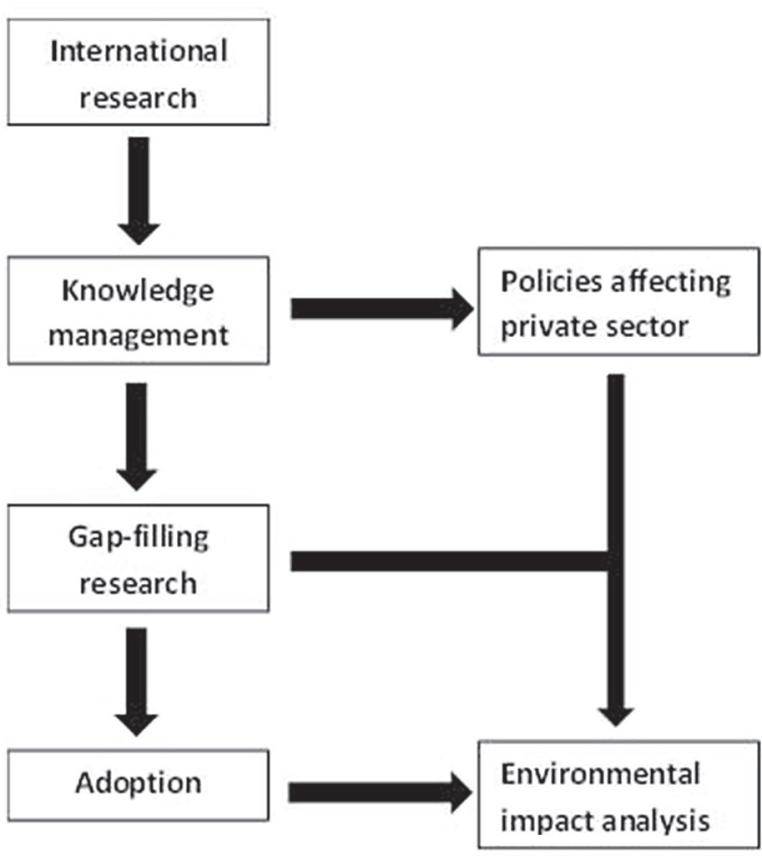

Figure 6 - A multidimensional model of agricultural technology transfer for the public sector.

Furthermore, the public financial support for independent researchers is insufficient. Potentially, national agricultural research and university research systems can diminish the expenditure of private research, providing skilled expertise for private agricultural research and innovation. National agricultural research could also possibly supply technologies in the private research sector to afford the opportunities that can be observed in developed nations in the West.

\section{CONCLUSIONS}

Fundamental components such as (a) national priorities, (b) specific research on agricultural sustainability, (c) adequate agricultural research and innovation, and (d) alternative policies, are required to promote sustainability research in agriculture and most importantly these should address recent environmental concerns. With this in mind, many emerging countries have proposed a mega science framework (MSF) for long-term 
sustainable development. However, MSF is facing many disputes and issues with legitimacy in achieving successful and sustainable agricultural development. To understand what makes an effective MSF, this study appraises barriers, policy gaps, desired technology and innovation and current lacks using the Malaysian perspective as a case study. Unlike some neighboring ASEAN countries, it has been noted that agriculture in Malaysia is not receiving sufficient attention from technology and research, which is a prerequisite for achieving sustainable development. This study has evaluated possible strategies for sustainable development in agriculture that can be merged with the MSF. The points addressed in this study can be used to revise the proposed MSF in Malaysia and in other countries with similar transitional economies.

\section{ACKNOWLEDGMENTS}

This work was supported by RG157-12SBS project funding by Geran Penyelidikan (UMRG)-SBS and UPGP, IPPP University Malaya. The authors would like to thank University of Malaya for financial support. The authors are also thankful to Naima Sharmin, a PhD student at the Faculty of Science who helped considerably with the figures of this manuscript preparation.

\section{RESUMO}

O significado de uma Agenda em Ciência (Scientific Framework - SF) atualmente tem recebido maior aceitação mundial para abordar a sustentabilidade da agricultura. Entretanto, profissionais defendem que o SF conhecido como Mega Agenda em Ciência (Mega Science Framework - MSF) nas economias em transição, não está convergindo efetivamente em muitos aspectos para a sustentabilidade agrícola. Particularmente nas economias em transição, o MSF é incapaz de identificar barreiras na pesquisa agrícola, é inadequado para delinear lacunas nas políticas que tenham o objetivo de elaborar estratégias para a sustentabilidade voltadas para a sustentabilidade desejada na tecnologia e inovação da agricultura, é inconsistente na busca para identificar desigualdades e incompleto para reconstruir decisões. Portanto, este estudo avalia criticamente os componentes do MSF nas economias em transição e examina significado, controvérsias e ilegitimidade para alcançar um desenvolvimento sustentável de sucesso. Um referencial científico confiável e eficaz pode ser desenvolvido quando ocorre uma ligação entre os principais componentes, tais como (a) prioridades nacionais, (b) pesquisa específica em sustentabilidade agrícola, (c) pesquisa e inovação adequadas em agricultura, e (d) política alternativa de mudança. Esse ensaio preliminar, que é o primeiro deste tipo, foi realizado com o objetivo de esboçar uma orientação política para construir uma efetiva agenda de ciência para a sustentabilidade agrícola.

Palavras-chave: Agenda de Ciência, desenvolvimento sustentável, agricultura sustentável, pesquisa e inovação.

\section{REFERENCES}

Alauddin M AND QUIGGIN J. 2008. Agricultural intensification, irrigation and the environment in South Asia: Issues and policy options. Ecol Econ 65: 111-124.

Aldy JE, HRUBovcaK J AND VASAVAdA U. 1998. The role of technology in sustaining agriculture and the environment. Ecol Econ 26: 81-96.

Alston JM, Chan-Kang C, Marra MC, PARdey PG AND WYATT TJ. 2000. A Meta-analysis of the Rates of Return to Agricultural R\&D: Ex pede Herculem? (Vol. 113). International Food Policy Research Institute.

Alston JM, PARdey PG AND SMith VH. 1998. Financing agricultural R\&D in rich countries: what's happening and why. Australian J Agr Resource Econ 42: 51-82.

AMINUdDin BY, GHULAM MH, ABDULlaH WW, ZULKEFL M AND SALAMA RB. 2005. Sustainability of current agricultural practices in the Cameron Highlands, Malaysia. Water, Air, \& Soil Pollution: Focus 5: 89-101.

ANDERSON K AND VALENZUELA E. 2008. Estimates of global distortions to agricultural incentives, 1955 to 2007 . World Bank, Washington, DC. Available at www.worldbank.org/ agdistortions.

ARSHAD MF, ISNAN ZM, IDRIS N, ALAM MF, NOH KM, ISMAIL I AND MoHDNON K. 2010. Is There a New Economic Model (NEM) for Agriculture? Kula Lumpur Malaysia. Options 15(1): 1-3.

ATHUKORALA PC AND LOKE WH. 2009. Agricultural Incentives in Malaysia: Trends, Patterns and Policy Implications. Malaysian J Econ Studies 46: 151-173. 
BAERENKLAU KA AND KeITH CK. 2007. Dynamics of agricultural technology adoption: Age structure, reversibility, and uncertainty. Amer J Agr Econ 89: 190-201.

BELL S AND MORSE S. 2004. Experiences with sustainability indicators and stakeholder participation: a case study relating to a 'Blue Plan' project in Malta. Sustain Dev 12: 1-14.

BLACKMORE S AND GRIEPENTROG HW. 2002. A future view of precision farming. KTBL Sonderveröffentlichung 38 : 131-145.

Bockstaller C, GiRardin P AND VAN Der Verf HM. 1997. Use of agro-ecological indicators for the evaluation of farming systems. Eur J Agron 7: 261-270.

Bossel H. 1998. Earth at a Crossroads: Paths to a Sustainable Future. Cambridge University Press, Cambridge.

Busch L, Bonanno A AND LaCY WB. 1989. Science, technology, and the restructuring of agriculture. Sociol Ruralis 29: 118-130.

ButTel FH. 1997. The politics and policies of sustainable agriculture: Some concluding remarks. Soc Nat Resour 10: 341-344.

CARruthers G AND TinNing G 2003. Where, and how, do monitoring and sustainability indicators fit into environmental management systems? Aust J Exp Agr 43: 307-323.

CAsh DW, Clark C, Alcock F, Dickson NM, ECKLEY N, Guston DH, Jager J AND Mitchell RB. 2003. Knowledge Systems for Sustainable Development, Proceedings of the National Academy of Sciences of the United States of America 100: 8086-8091.

Cerf M, Guillot MN And Olry P. 2011. Acting as a change agent in supporting sustainable agriculture: How to cope with new professional situations? J Agr Edu Ext 17: 7-19.

ChichiLnisky G. 1994. North-South trade and the global environment. American Economic Review 84: 851-874.

CORBIERE-NICOLLIER T, FERRARI Y, JEMELIN C AND JOLLIET O. 2003. Assessing sustainability: an assessment framework to evaluate Agenda 21 actions at the local level. Int J Sust Dev World 10: 225-237.

DOS. 2010. Economic Report, Various Issues. Ministry of Finance, Department of Statistics, Malaysia.

EASYPOL. 2006. Policy Highlights Agricultural Technology: Research and Extension Systems, by Agricultural Policy Support Service, Policy Assistance Division, FAO, Rome, Italy based on Chapter 5 of Agricultural Development Policy: Concepts and Experiences by Roger D. Norton for the Food and Agriculture Organization of the United Nations, FAO.

EPU. 2006. Ninth Malaysia Plan 2006-2010. Economic Planning Unit; Government of Malaysia.

EPU. 2014. Comparative expenditure and R\&D in Malaysia. Economic Planning Unit (EPU), Putrajaya, Malaysia.

ERVIN DE, GLenNA LL AND Jussaume RA. 2010. Are biotechnology and sustainable agriculture compatible? Renewable Agr and Food Syst 25: 143-157.

EU. 2011. Innovation Union Competitiveness Report: Analysis-Part I: Investment and performance in R\&D Investing in the future. European Union.
FAN S, QIAN K AND ZHANG X. 2006. China: An unfinished reform agenda. Agricultural R\&D in the developing world: too little, too late? Pardey PG, Alston JM and Piggott RR (Eds), International Food Policy Research Institute, Washington DC.

Fraser EDG, Dougill AJ, MABeE W, ReEd MS AND MCALPINE P. 2006. Bottom up and top down: analysis of participatory processes for sustainability indicator identification as a pathway to community empowerment and sustainable environmental management. J Environ Manage 78: 114-127.

GibBons M. 1994. The New Production of Knowledge: The Dynamics of Science and Research in Contemporary Societies, London: Sage.

Gibbons M, Limoges C, Nowotny H, Schwartzman S, SCOTT P AND TROW M. 1994. The new production of knowledge: the dynamics of science and research in contemporary societies. London: Sage press.

HeLlin J. 2012. Agricultural extension, collective action and innovation systems: Lessons on Network Brokering from Peru and. J Agr Edu Ext 18:141-159.

HEZRI AA AND HASAN MN. 2004. Management framework for sustainable development indicators in the state of Selangor, Malaysia. Ecolog Ind 4: 287-304.

Hopwood B, GidDINGS B AND O'BRIEN G. 2002. Environment, economy and society: fitting them together into sustainable development. Sustain Dev 10: 187-196.

Hopwood B, Mellor M ANd O'Brien G. 2005. Sustainable Development: Mapping Different Approaches. Sustain Dev 13: 38-52.

KoEHNEN TL. 2011. ICTs for Agricultural Extension. Global Experiments, Innovations and Experiences ICTs for Agricultural Extension. Global Experiments, Innovations and Experiences 17: 473-474.

Koutsouris A. 2008. Innovating towards sustainable agriculture: A Greek case study. J Agr Edu Ext 14: 203-215.

LEEUwIS C. 2000. Learning to be Sustainable. J Agr Edu Ext 7: 79-92.

LIU P AND ZHANG X. 2011. Investigation into evaluation of agriculture informatization level based on two-tuple. Tech Econ Dev Economy 17: 74-86.

LEDERMAN NG. 2006. Research on nature of science: reflections on the past, anticipations of the future. In Asia-Pacific Forum on Science Learning and Teaching 7(1): 1.

MANAP AM. 1986. Malaysian agriculture: agroforestry options. In: Wong KC, Hashim A, Mohd Khalid MN and Mohd Yusuf S. Options for Malaysian agriculture. Agricultural Institute Press, Malaysia, p. 101-135.

Mantell S AND Van Hove P. 2008. Briefing: Agriculture and development. Proceedings of the ICE-Engineering Sustainability 161: 157-159.

Meadows DB, Meadows DL And Randers J. 1992. Beyond the limits: global collapse or a sustainable future. Earthscan Publications Ltd. 
MiLler R. 2006. Twenty first century science: Insights from design and implementation of a scientific literacy approach in school science. Int J Sci Edu 28: 1499-1521.

MSF - Mega Science Framework Study. 2010. A megascience framework for sustained national development: an overview, Country report, Paper Number: 02-2010/11. Academy of Science Malaysia.

MULDER M. 2012. Innovative approaches for agricultural knowledge management. J Agr Edu Ext 18: 99-102.

Mullen JD, Vernon D AND FishroOL KI. 2000. Agricultural extension policy in Australia: public funding and market failure. Aust J Agric Resour Econ 44: 629-645.

NAVARRO M. 2006. How can agricultural and extension educators contribute to a successful new green revolution? J Agr Edu Ext 12: 83-96.

NEP. 2010. New economic model: Part-I: Strategic Policy Directions. National Economic Advisory Council, Federal Government Administrative Centre, Malaysia.

PARdey PG, Alston JM AND PigGot RR. 2006. Agricultural R\&D Policy in the participation: a case study relating to a 'Blue Plan' project in Malta. Sustain Dev 12: 1-14.

PRASAD LP. 2012. Learning and Innovation Competence in Agricultural and Rural Development. J Agr Edu Ext 18: 205-230.

RAHIM RA AND EMRAN NM. 2012. Streamlining Malaysia's National R\&D Areas. Problemy Eksploatacji, p. 139-150.
RaO CHH AND HanUmantha RaO CH. 2005. Agriculture, food security, poverty, and environment: essays on postreform India. Oxford University Press.

REED MS, FRASER EDG AND DOUGILl AJ. 2006. An adaptive learning process for developing and applying sustainability indicators with local communities. Ecol Econ 59: 406-418.

RUKMANI R. 2008. Measures of impact of science and technology in India: agriculture and rural development. Curr Sci India 95: 1694-1698.

SANDALl J, COOKSEY R AND Wright V. 2011. A Systems Approach to Identifying and Managing Opportunities and Constraints to Delivering Innovation Policy for Agriculture: An Analysis of the Australian Cooperative Research Centres (CRC) Program. J Agr Edu Ext 17: 411-423

SHARMISTHA S AND RICHARD G. 2007. Economic Development and the Role of Agricultural Technology. Agr Econ 36: 395-404

Sulaiman VR, HALl A, Kalaivani NJ, DORAI K AND REDDY TV. 2012. Necessary, but not sufficient: Critiquing the role of information and communication technology in putting knowledge into use. J Agr Edu Ext 18: 331-346.

ZAINAL AY AND BHATTASALI D. 2008. Economic growth and development in Malaysia: Policy making and leadership. Working paper no. 27. World Bank, Washington, D.C. USA. 